\title{
PRODUKSI KONTEN MULTIMEDIA UNTUK IBADAH ONLINE HKBP PERUMNAS TANGERANG SELAMA MASA PADEMIC COVID-19
}

\author{
Jumadal Simamora \\ Fakultas Ilmu Sosial dan Ilmu Politik \\ Universitas Pelita Harapan, Karawaci - Tangerang \\ jumadal.simamora@uph.edu
}

\begin{abstract}
Abstrak
Wabah virus Corona atau yang disebut dengan Coronavirus Diseas 2019 (Covid-19) telah mengubah tatanan kehidupan masyarakat dunia dalam waktu singkat. Sejak pertama kali ditemukan di Wuhan pada akhir tahun 2019, wabah virus Covid-19 dengan cepat menyebar secara global. Di Indonesia, Covid -19 pertama kali dikonfirmasi pada 2 Maret 2020. Seiring dengan itu, pemerintah mengambil tindakan dan langkah langkah strategis membatasi penyebaran virus tersebut seperti pembatasan sosial (Physical Distancing). Upaya itu dilanjutkan dengan kebijakan kerja dari rumah, belajar dari rumah dan beribadah dari rumah. Untuk mendukung langkah pemerintah, gereja HKBP Perumnas Tangerang juga menghentikan ibadah mingguan di gereja untuk dewasa dan sekolah minggu dan menggantikannya dengan ibadah keluarga yang dilaksanakan di rumah masing-masing. Tentu ibadah keluarga di rumah sangat berbeda dengan ibadah berjemaah yang biasa dilakukan di gereja. Di rumah, ibadah dilaksanakan hanya menggunakan tata ibadah yang dibagikan secara tercetak tanpa dipimpin penatua atau pendeta. Untuk mengatasi kendala itu, kegiatan PkM ini bertujuan untuk menyediakan video ibadah yang dipimpin oleh pendeta dan dapat diakses oleh seluruh jemaat melalui online. Adapun metode yang dilakukan adalah perekaman video kotbah pendeta, kemudian mengedit dan mengunggah di Youtube. Hasil dari PkM ini adalah konten Youtube HKBP Perumnas yang berisi kotbah pendeta, lagu pujian setiap minggu dan rekaman ibadah untuk sekolah minggu HKBP. Dengan demikian, jemaat tetap dapat mengikuti ibadah dan kotbah dari pendeta sekalipun ibadah dilaksanakan di rumah masing-masing.
\end{abstract}

Kata kunci: Covid-19, ibadah Online, HKBP, multimedia.

\section{PENDAHULUAN}

Sejak pertama kali virus Corona ditemukan di kota Wuhan, China pada tahun akhir 2019, virus ini dengan cepat menyebar secara global, termasuk ke Indonesia. Virus Corona atau disebut juga Coronavirus Diseas 2019 (Covid-2019) adalah salah satu jenis virus yang menyerang sistem pernapasan manusia hingga dapat menyebabkan kematian. Hingga Kamis, 10 September 2020, tercatat jumlah kasus virus Corona di dunia, 27.985.744 dengan
906.646 meninggal dunia dan 20.061.242 dinyatakan sembuh (Kompas.com.10 September 2020).

Di Indonesia, kasus virus Corona pertama kali dikonfirmasi pada 2 Maret 2020. Korban kasus pertama ini menimpa 2 orang yaitu seorang ibu dan putrinya warga Depok, Bogor, Jawa Barat. Tidak berselang lama, penyebaran virus Corona semakin meningkat. Pada 27 Maret 2020, tercatat kasus Covid 19 sudah mencapai 1046 dengan 87 orang meninggal dan 46 orang sembuh dari kasus Covid. (detik.com, 2 September 2020).

Teknologi Informasi dan Komunikasi 
Untuk mencegah dan menanggulangi dampak penyebaran virus Corona di Indonesia, Presiden membentuk gugus tugas Covid-19 pada 13 Maret 2020. Gugus Tugas ini dibentuk untuk mengkoordinasikan sinergi kegiatan antar lembaga/kementerian dan pemerintah daerah sehingga penanganan Covid 19 bisa lebih maksimal. (katadata.co.id, 13 Maret 2020). Selain upaya kuratif, melalui berbagai media, pemerintah melakukan kampanye Perilaku Hidup Sehat dan Bersih (PHSB). Dibeberapa daerah, atas seijin menteri kesehatan, pemerintah menerapkan protokol Pembatasan Sosial Berskala Besar (PSBB). Seiring dengan itu, untuk menekan penyebaran Covid-19, pada 15 Maret 2020 presiden Jokowi menghimbau agar masyarakat beraktivitas bekerja, belajar dan beribadah dari rumah (setkab.go.id, 15 Maret 2020).

Merespon kebijakan pemerintah, sejumlah kantor melaksanakan aktifitasnya dari rumah. Aktivitas belajar mengajar di sekolah juga diberhentikan dan diganti melalui metode pengajaran online. Demikian juga kegiatan keagamaan berjemaah di tempat ibadah juga mulai ditutup sementara dan dilakukan di rumah masing-masing.

Sebagai salah satu gereja yang turut mendukung program pemerintah, sejak pertengahan Maret 2020 gereja HKBP Perumnas Tangerang mulai menghentikan kegiatan ibadah di gereja dan digantikan dengan ibadah di rumah masing-masing. Model ibadah di rumah tentu sangat berbeda dengan ibadah yang diadakan di gereja. Ibadah di gereja biasanya dipimpin oleh para pelayan, mulai dari penatua yang memimpin liturgis, nyayian pujian dipimpin oleh pemimpin pujian dan kotbah dibawakan oleh pendeta. Sementara ibadah di rumah, jemaat hanya mengikuti tata ibadah yang telah disiapkan oleh gereja dalam bentuk fotocopy. Dalam ibadah di rumah, liturgi dibawakan oleh salah satu anggota keluarga, kemudian kotbah dibacakan oleh kepala keluarga.

Metode ibadah di rumah dengan hanya mengikuti teks tata ibadah dirasakan jemaat kurang menarik dan mereka menginginkan agar kotbah tetap disampaikan oleh pendeta. Kendala lainnya, pada saat ibadah dilakukan di rumah, sebagian jemaat belum lancar mengikuti tone lagu pujian, sehingga mereka tidak dapat mengikuti irama lagu pujian dengan tepat.
Melihat fenomema tersebut maka penatua gereja meminta solusi melalui Pengabdian Kepada Masyarakat (PkM). Untuk mengatasi masalah di atas, pendekatan yang digunakan dalam $\mathrm{PkM}$ ini adalah pendekatan multimedia. Menurut Munir (2012:20 multimedia adalah perpaduan antara berbagai media (format file) berupa teks, gambar, grafik, audio, animasi, video, interaksi dan lain-lain yang dikemas menjadi file digital dan digunakan untuk menyampaikan atau menghantarkan pesan kepada publik. Sedangkan menurut Turban dkk (2002) dalam Suyanto $(2005,21)$ multimedia adalah kombinasi paling sedikit dua media input atau output dari data, yang terdiri dari audio (suara, musik), animasi, video, teks, grafik dan gambar.

Karena terdiri dari beberapa elemen, multimedia dapat mengembangkan kemampuan indera dan menarik perhatian serta minat dari audiens. Hasil penelitian Computer Tecnology Research (CTR) sebagaiman dikutip Munir $(2012,6)$ mengemukakan bahwa orang hanya mampu mengingat $20 \%$ dari yang dilihat dan $30 \%$ dari yang didengar. Lebih lanjut, orang dapat mengingat $50 \%$ dari yang dilihat dan didengar, kemudian $80 \%$ dari yang dilihat, didengar dan dilakukan sekaligus. Kemampuan multimedia yang dapat menyajikan informasi yang dapat dilihat, didengar dan dilakukan membuat multimedia menjadi alat yang efektif untuk menyampaikan pesan kepada audiens.

Menurut Munir (2012,16), elemen-elemen multimedia terdiri dari teks, gambar, suara, animasi, video. Penjelasan dari elemen-elemen tersebut adalah sebagai berikut:

1. Teks

Teks adalah kombinasi huruf yang membentuk satu kata atau kalimat yang menjelaskan suatu maksud atau materi pembelajaran yang dapat dipahami oleh orang yang membacanya. Teks merupakan salah satu komponen multimedia yang sangat ampuh dan jelas dalam penyampaian informasi. Penggunaan teks misalnya digunakan pada judul menu, menu-menu, dan tombol. Penggunaan teks pada multimedia perlu mempertimbangkan penggunaan jenis huruf, ukuran huruf, dan style huruf seperti warna, bold dan italic.

2. Gambar

Gambar merupakan penyampai informasi dalam bentuk visual. Gambar merupakan komponen multimedia yang dapat menyampaikan informasi lebih menarik. Gambar sangat berguna untuk Teknologi Informasi dan Komunikasi 
menyampaikan informasi yang tidak dapat dijelaskan dengan kata-kata. Gambar yang dihasilkan oleh komputer terbagi menjadi dua, yaitu:

a) Bitmaps: yaitu gambar yang terdiri dari titiktitik kecil yang membentuk sebuah gambar.

b) Vector drawn: yaitu gambar yang dihasilkan dari koordinat Cartesian yang biasanya menghasilkan bentuk garis, lingkaran, kotak, dan sebagainya.

\section{Suara}

Suara merupakan komponen yang paling mengena oleh panca indera manusia. Adio atau suara dapat juga didefiniskan sebagai berbagai macam bunyi dalam bentuk digital seperti suara, musik, narasi dan sebagainya yang bisa didengar untuk keperluan suara, penyampai pesan sedih, semangat yang dapat disesuaikan dengan situasi dan kondisi. Dengan demikian audio dapat memberikan kesenangan seperti dalam mendengarkan musik, atau dapat memberikan suasana yang dapat mengubah mood seseorang.

\section{Animasi}

Animasi merupakan komponen multimedia yang dapat membuat suatu gambar atau tulisan terlihat lebih hidup dengan menampilkan potonganpotongan gambar yang berganti-ganti secara cepat. Selain itu animasi juga dapat membuat slide presentasi menjadi lebih menarik. Contoh animasi seperti tweening, fade in, fade out, zoom in, zoom out, dan sebagainya.

5. Video

Video merupakan komponen multimedia yang terdiri dari gambar-gambar dan bergerak dengan sangat cepat secara berurutan. Video merupakan komponen paling menarik dalam multimedia, dan video juga memiliki kekuatan untuk membawa pengguna komputer lebih dekat ke kehidupan nyata. Dengan menambahkan komponen video di dalam project, dapat menyampaikan pesan dan memperkuat cerita. Selain itu orang-orang yang melihat video cenderung dapat mengingat lebih dari yang mereka lihat. Oleh karena itu, video menyediakan sumber daya yang kaya dan hidup bagi applikasi multimedia.

Elemen-elemen multimedia di atas akan digunakan untuk mengatasi masalah mitra, terutama elemen video. Video dapat digunakan sebagai sumber utama penyebaran informasi, karena audiens akan lebih senang melihat informasi yang disampaikan melalui gambar bergerak dibanding hanya tulisan saja.

Oleh karena itu, solusi yang akan dilakukan untuk mengatasi permasalahan mitra adalah melakukan perekaman video kotbah yang dibawakan langsung oleh pendeta dan Nyanyian Pujian yang dipimpin oleh team musik dan song leader. Rekaman tersebut akan diedit dan ditambahkan komponen multimedia seperti audio, teks, animasi dan gambar. Selanjutnya video yang sudah diedit akan diunggah ke Youtube. Link (tautan) video di Youtube kemudian akan dibagikan (share) melalui applikasi grup Whatsapp ke jemaat.

Youtube merupakan salah satu applikasi media sosial yang dapat digunakan untuk mengunggah video dan dapat dibagikan (share) kepada orang lain melalui jaringan internet. Di Youtube terdapat video-video yang telah diunggah baik itu dari institusi maupun individual. Di Youtube, pengguna dapat membuat account sendiri secara gratis. Didalammnya juga terdapat fitur siaran langsung (Live streaming) dan fitur komentar yang memungkinkan audiens dapat memberikan komentar pada video yang ditonton.

Applikasi Youtube sangat potensial digunakan sebagai alternatif sarana ibadah online. Kepemilikikan perangkat digital dan akses internet yang semakin terjangkau membuat masyarakat sangat akrab dengan Youtube. Selain melalui komputer PC, Laptop, Youtube juga dapat diakses melalui smartphone sepanjang pengguna memiliki kuota internet. Menurut We Are Social, Hotsuit (2020) sebagaimana dikutip Databoks (databoks, 26 Feb 2020), Youtube merupakan salah satu media sosial menempati peringkar pertama yang paling sering digunakan masyarakat Indonesia yakni dengan jumlah $88 \%$ dari pengguna internet, kemudian diikuti media sosial Whatsaap dengan 84\% Pengguna. 10 media sosial yang paling sering digunakan dapat dilihat pada grafik di bawah ini. 
10 Media Sosial yang Sering Digunakan 2020

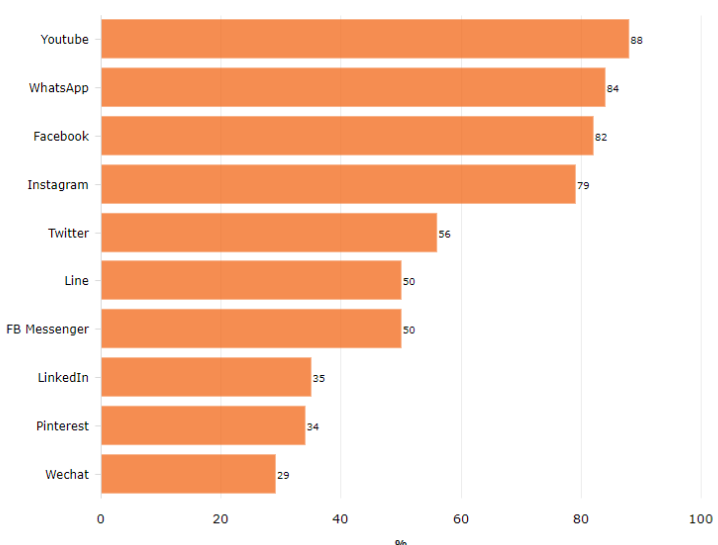

Gambar 1. 10 Media Sosial yang paling sering digunakan tahun 2020 di Indonesia.

Sumber: databoks.katadata.co.id

Selain diunggah di Youtube, video yang diproduksi akan ditautukan ke situs atau website HKBP perumnas Tangerang. Menurut Nasrullah $(2014,25)$ situs (Web Site) adalah halaman yang merupakan satu alamat domain yang berisi informasi, data, visual, audio, memuat applikasi, hingga berisi tautan dari halaman web lainnya. HKBP Perumnas Tangerang telah memiliki website dengan urrl: https://hkbp-perumnas-tangerang.org/

Dari uraian dan latar belakang di atas, maka tujuan dari PkM ini adalah adalah untuk memfasilitasi gereja HKBP Perumnas 1 Tangerang yaitu menyediakan tayangan multimedia ibadah online selama Covid-19, sehingga jemaat tetap dapat mengikuti ibadah yang dipimpin oleh pendeta, sekalipun ibadah di lakukan di rumah masingmasing. Pendekatan yang digunakan adalah pendekatan multimedia dengan memanfaatkan media sosial Youtube dan Website. Lebih detail, metode yang akan dilaksanakan akan dijelaskan pada sub bab berikut ini.

\section{METODE}

Untuk memberikan solusi atas masalah yang dihadapi mitra, PkM ini akan memproduksi tayangan multimedia untuk ibadah online HKBP Perumnas Tangerang. Setelah melihat permasalahan yang dihadapi dan berdiskusi dengan mitra, maka langkah-langkah sistematis yang dilakukan untuk produksi konten multimedia sebagai materi ibadah online HKBP Perumnas Tangerang dibagi dalam 4 tahapan yaitu, 1). Persiapan, 2). Produksi dan 3). Post-produksi atau Editing dan, 4). Upoading ke Youtube.

1. Tahap Persiapan dan Kooordinasi.

Pada tahap ini, dilakukan kordinasi dengan semua team yang terlibat, pendeta yang membawakan kotbah, singer (pemimpin pujian) dan tim musik yang akan mengiringi lagu dan selanjutnya menentukan jadwal perekaman gambar. Grup Whatapps menjadi salah satu sarana untuk melakukan koordinasi dengan semua team yang terlibat. Pada tahap ini juga dipersiapkan peralatan yang digunakan untuk perekaman gambar seperti kamera video, tripod dan microphone. Berhubung gereja tidak memiliki peralatan kamera, maka peralatan video yang digunakan adalah video kamera milik salah satu anggota jemaat.

\section{Tahap Produksi.}

Tahapan produksi adalah tahap perekaman gambar sesuai dengan jadwal yang telah disepakati. Pada tahapan ini, kotbah pendeta dan lagu pujian direkam. Untuk memberikan waktu mengedit video, jadwal pengambilan gambar setiap minggunya dilakukan pada hari Kamis atau Jumat, sehingga ada waktu untuk mengedit dan memasukkan video ke Youtube. Perekaman gambar akan dilakukan setiap minggu.

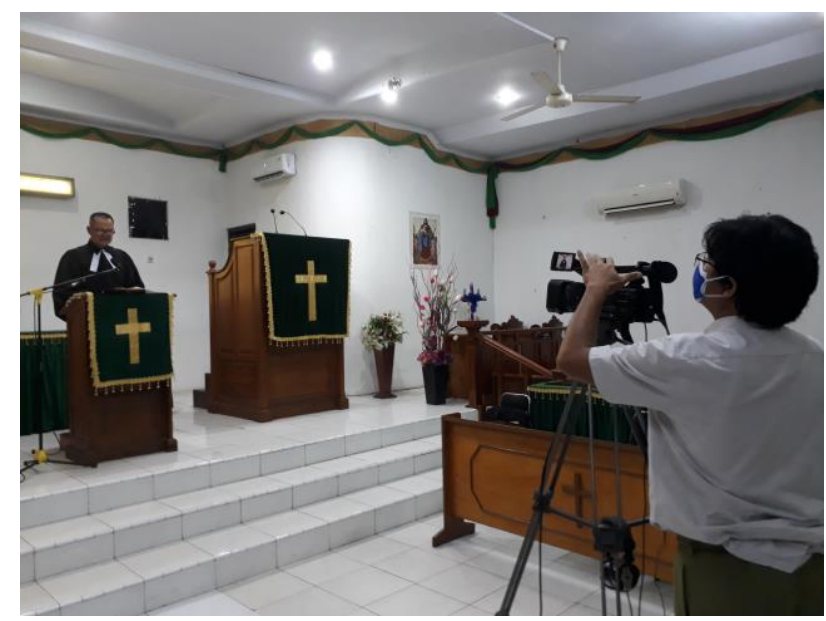

Gambar 2. Proses Perekaman Kotbah Pendeta 


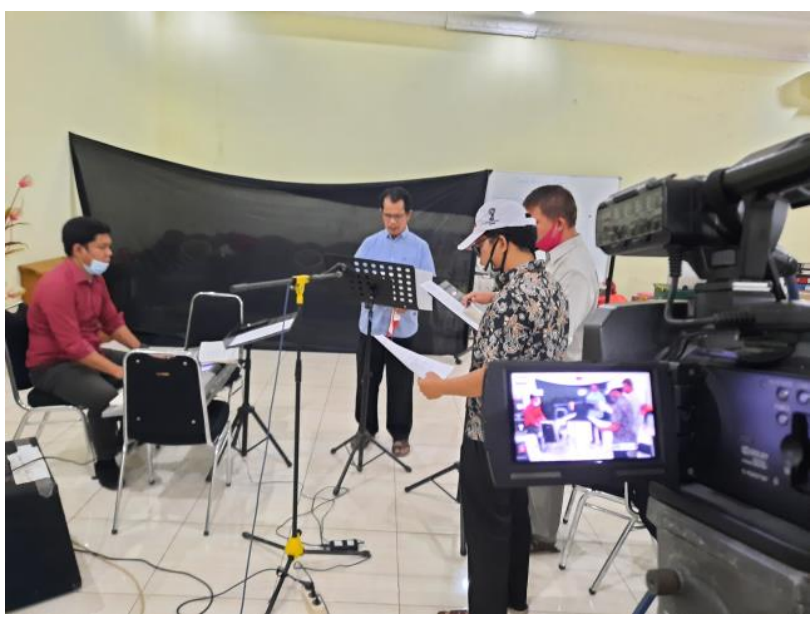

Gambar 3. Proses Perekaman gambar tim musik dan Singer

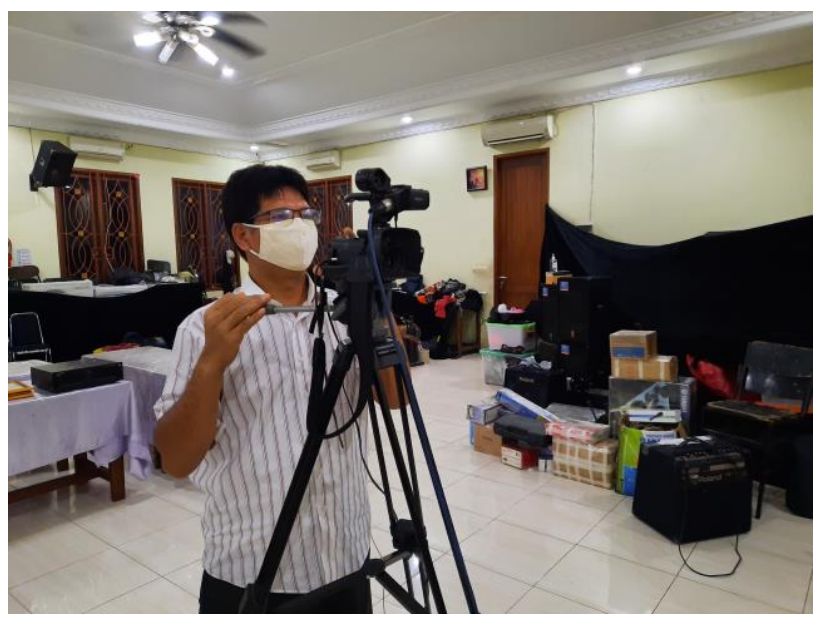

Gambar 4. Proses Perekaman gambar oleh tim video

3. Editing Video (Post-Produksi).

Setelah gambar direkam, tahap selanjutnya adalah pengeditan video. Proses pengeditan adalah membuang video yang salah dan memilih gambar yang akan digunakan. Kemudian menambahkan judul, teks, musik background, sehingga lebih menarik dan lebih bermakna. Music backgroud menggunakan intrument dan musik dari Youtube.

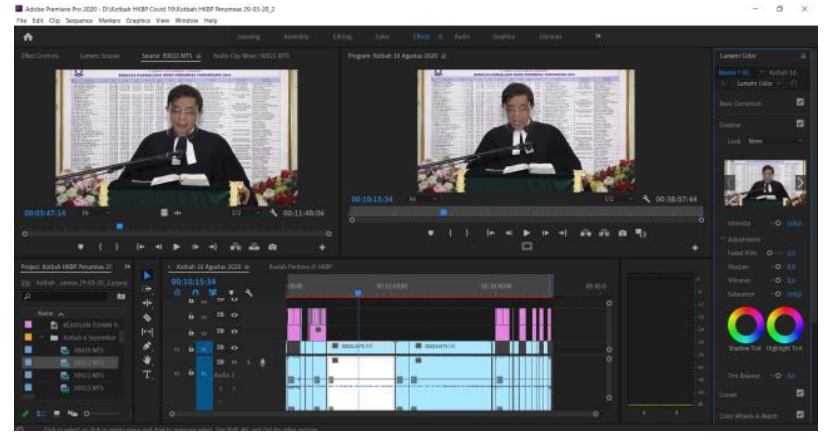

Gambar 5. Proses editing menggunakan applikasi Adobe Premiere.

Pada saat editing, nats alkitab (firman) sebagai topik kotbah yang dibacakan pendeta dimasukkan pada saat editing. Demikian juga teks lagu pujian, akan memudahkan jemaat dalam mengikuti ibadah.

4. Upload video ke Youtube Channel dan Share tautan (link) ke Jemaat.

Setelah video selesai diedit, tahapan berikutnya adalah proses unggah video ke account Youtube Channel HKBP Perumnas Tangerang. Sebelumnya telah dibuatkan account Youtube Channel HKBP di Youtube, yakni HKBP Perumnas 1 Tangerang. Waktu yang dibutuhkan untuk proses unggah tergantung dari durasi video dan kecepatan internet yang digunakan. Untuk memudahkan pencarian video di Youtube, informasi judul, deskripsi dan tag harus dibuat sejelas mungkin, sehingga jemaat yang mau mengakses video akan mudah menemukan video tersebut. Setelah selesai unggah, tautan atau link video di Youtube selanjutnya dibagikan kepada jemaat menggunakan applikasi Whatsapp Group. Jemaat yang sudah mendapatkan tautan akan dengan mudah mengakses video di Youtube.

Selain upload ke Youtube, video kotbah dan ibadah online sekolah minggu juga dimasukkan ke website HKBP Perumnas Tangerang dengan url: https://hkbp-perumnas-tangerang.org/

\section{HASIL DAN PEMBAHASAN}

\section{Hasil PkM}

Sejak ibadah minggu dilakukan di rumah, mulai Maret hingga September 2020 video yang telah diproduksi dan diunggah ke Youtube berjumlah 44

Teknologi Informasi dan Komunikasi 
video dengan rincian 27 video Ibadah keluarga untuk dewasa dan 17 ibadah untuk sekolah minggu. Video yang difokuskan adalah video ibadah yang ditujukan kepada orang dewasa. Video ibadah sekolah minggu diproduksi oleh tim guru Sekolah Minggu. Selain itu, beberapa video dokumentasi kegiatan gereja juga diupload di Youtube agar dapat disaksikan oleh anggota jemaat.

Pada bulan Maret, video yang diproduksi dan diunggah untuk ibadah dewasa hanya satu dan merupakan video yang pertama. Video ini ditonton 754 views dan penambahan 34 subscriber. Kemudian sepanjang bulan April video yang diproduksi dan diunggah ke Youtube berjumlah 4 video. Pada bulan Mei 2020, 6 video yang diupload. Kemudian pada bulan Juni 2020, video yang diproduksi dan diupload berjumlah 5 video. Pada bulan Juli 2020 berjumlah 3 video. Agustus ada 5 video dan sementara pada September sebanyak 4 video.

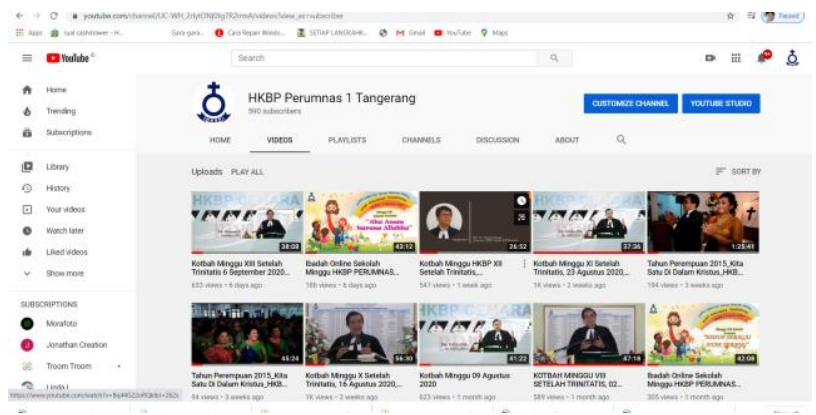

Gambar 6. Tampilan Video-Video yang diunggah di Youtube Channel HKBP Perumnas Tangerang.

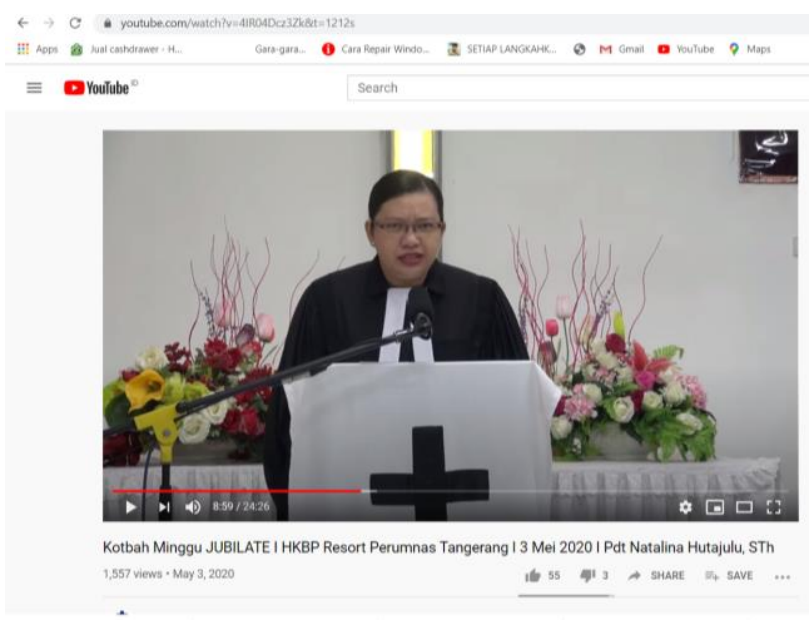

Gambar 7. Tampilan salah satu video kotbah pendeta yang diunggah ke Youtube Channel HKBP Perumnas Tangerang.

\section{Pembahasan}

Merebaknya wabah virus Corona telah membawa perubahan secara mendadak di masyarakat. Khusus di bidang keagamaan, migrasi dari ibadah offline ke ibadah online menjadi salah satu alternatif untuk mengatasi masalah dan membatasi penyebaran virus Covid-19.

PkM dengan tema "Produksi konten multimedia untuk ibadah online HKBP Perumnas 1 Tangerang" menjadi solusi dan bermanfaat yang dirasakan seluruh jemaat. Mereka dapat menikmati ibadah yang dipimpin oleh Pendeta, sekalipun melalui online di Youtube.

Tabel 1. Penonton Youtube Channel HKBP Perumnas 1, Periode 28 Maret - September 2020

\begin{tabular}{|c|c|c|c|c|}
\hline \multirow[b]{2}{*}{ Viewer age } & \multicolumn{2}{|c|}{ Views } & \multicolumn{2}{|c|}{ Watch time (hours) } \\
\hline & Female & Mate & Female & Male \\
\hline Total & $51.1 \%$ & $48.9 \%$ & $53.2 \%$ & $46.9 \%$ \\
\hline 13-17 years & $1.3 \%$ & $0.3 \%$ & $0.5 \%$ & $0.2 \%$ \\
\hline $18-24$ years & $7.7 \%$ & $7.5 \%$ & $7.0 \%$ & $7.6 \%$ \\
\hline 25 - 34 years & $12.4 \%$ & $10.6 \%$ & $12.0 \%$ & $8.6 \%$ \\
\hline $35-44$ years & $10.0 \%$ & $9.2 \%$ & $10.2 \%$ & $9.4 \%$ \\
\hline 45-54 years & $8.5 \%$ & $10.9 \%$ & $10.1 \%$ & $9.9 \%$ \\
\hline $55-64$ years & $8.8 \%$ & $8.0 \%$ & $10.6 \%$ & $8.5 \%$ \\
\hline $65+$ years & $2.5 \%$ & $2.6 \%$ & $2.7 \%$ & $2.7 \%$ \\
\hline
\end{tabular}

Berdasarkan analisis dari media sosial Youtube di atas, penonton channel Youtube HKBP Perumnas 1 Tangerang berdasarkan jenis kelamin memiliki presentasi dengan selisih hampir berimbang, dengan rincian jenis kelamin laki-laki, 51,1 \% dan perempuan $48,9 \%$. 


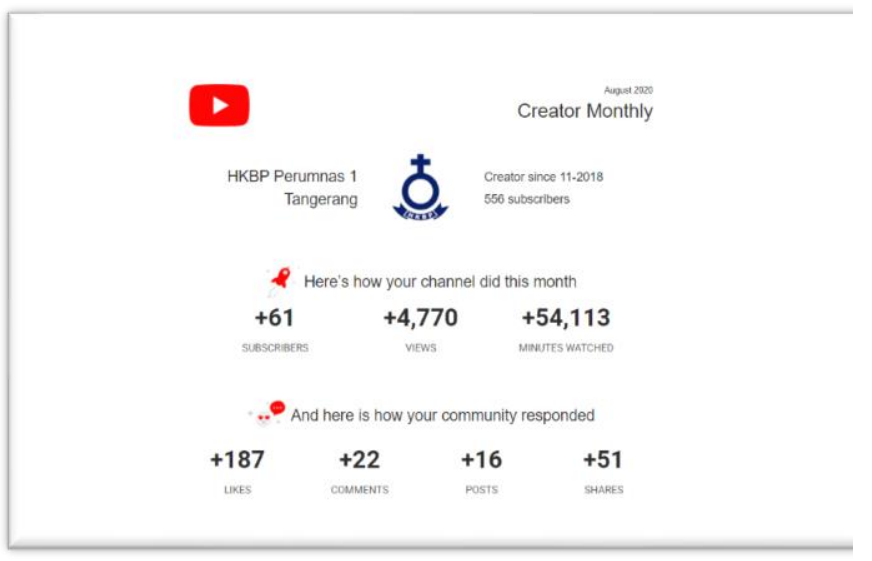

Gambar 8. Hasil Analisis Youtube Channel Agustus 2020.

Dari video-video yang diunggah di Youtube dapat dilihat bahwa video-video tersebut dapat diakses oleh jemaat. Sebagaimana karakteristik media baru, interaktif, melalui media sosial Youtube, audiens dapat memberikan komentar dan like. Video yang diupload di Youtube selalu mendapat respon berupa like dan komentar yang positif.

Dalam praktiknya, sekalipun ibadah dapat difasilitasi melalui online Youtube, namun sebagian jemaat tetap mengalami kendala, yaitu keterbatasn kuota internet. Akibatnya, ibadah minggu tidak sepenuhnya dilaksanakan melalui online. Ibadah online melalui Youtube, dimulai dari lagu pengantar kotbah, kotbah pendeta hingga doa penutup. dari awal hingga selesai.

Dalam produksi video ini menjadi perlu untuk , di era digital sekarang ini, semakin mudah mengambil data digital dari internet dan menggunakan ulang data tersebut. Namun juga perlu diperhatikan terkait Hak Cipta. Dalam video yang diproduksi dan diunggah di Youtube beberapa video mendapat notifikasi dari Youtube bahwa ada bagian yang digunakan dan melanggar hak Cipta. Bahkan ada satu video yang di-remove karena terkait hak Cipta. Berdasarkan pengalaman tersebut, videovideo berikutnya harus memperhatikan Hak Cipta untuk video-video yang sumbernya dari internet.

\section{KESIMPULAN}

PkM yang dilakukan pada situasi Covid-19 berjalan dengan baik dan memiliki manfaat yang baik bagi jemaat HKBP Perumnas Tangerang. Dengan adanya $\mathrm{PkM}$ dengan tema "Produksi Konten Multimedia untuk Ibadah Online HKBP Perumnas Tangerang Selama Masa Pademic Covid-19, dapat menjadi alternatif solusi bagi jemaat dalam melakukan ibadah. Jemaat tetap dapat melakukan ibadah di rumah dan mendengarkan kotbah langsung dari pendeta melalui Youtube.

Sebagaimana konsep multimedia yang mengetengahkan video, teks, audio, gambar dan animasi dapat lebih menarik perhatian audiens dibanding dengan hanya membaca teks yang sebelumnya digunakan.

Kerjasama PkM dengan Mitra HKBP senantiasa perlu dilanjutkan. Sebagai informasi, pada 2019 lalu, PkM dengan tema Produksi Konten Multimedia untuk Website HKBP Perumnas Tangerang telah dilaksanakan. Sebagian perserta pelatihan tersebut ikut terlibat dalam produksi video, khususnya produksi video untuk ibadah online sekolah minggu HKBP Perumnas Tangerang. PkM ini merupakan kelanjutan dari PkM yang sudah pernah dilakukan dengan judul "Pegelolaan Website dan Produksi Konten Multimedia Untuk Website HKBP Perumnas Tangerang" pada bulan Juni 2019. Diharapkan dengan kerjasama ini, mitra dapat merasakan manfaat yang lebih signifikan dengan kegiatan kerjasama yang dilakukan.

\section{UCAPAN TERIMA KASIH}

Puji syukur kami panjatkan kepada Tuhan sehingga PkM dengan judul "Produksi Konten Multimedia Untuk Ibadah Online HKBP Perumnas Tangerang Selama Masa Pademic Covid-19”, bisa terselenggara dengan baik dan memiliki dampat yang baik bagi jemaat HKBP Perumnas Tangerang.

Secara khusus kami mengucapkan terima kasih atas bantuan dan berbagai pihak sehingga PkM ini bisa berjalan dengan baik:

1. Ketua Program Studi Ilmu Komunikasi, Marsefio Luhukay, S.Sos., M.Si, yang telah mendukung sehingga PkM ini bisa terlaksana dengan baik.

Teknologi Informasi dan Komunikasi 
2. Pendeta M. H. Sidabutar sebagai pimpinan jemaat gereja HKBP Perumnas Tangerang, Banten yang telah mengkoordinir semua tim online HKBP Perumnas Tangerang.

3. Pendeta Natalina Hutajulu dan Pendeta Pasaribu atas kerjasama yang baik selama proses perekaman.

4. Tim singer, St. Simarmata, St. Sindak Roy Simaremare dan St. B. Pakpahan atas kerjasma yang baik selama perekaman lagu pujian.

5. Tim musik, D. Sianturi dan Sidabutar.yang setia mengiringi setiap lagu, sehingga proses perekaman bisa berjalan dengan lancar.

6. Adelina Silitonga sebagai tim administrasi yang telah membantu proses surat menyurat selama PkM ini dilaksanakan.

7. Ewy Jaya Simamora sebagai pemilik 'Mora Foto" sekaligus jemaat HKBP Perumnas Tangerang yang telah meminjamkan peralatan Camera Video untuk perekaman setiap minggu. Selain itu juga ikut bekerjasama dalam perekaman dan editing video.

\section{REFERENSI}

Bayu, Dimas Jarot. Katadata.co.id. (13 Maret 2020). Jokowi Bentuk Tugas Percepatan Penanganan Covid-19. Diakses pada 25 September 2020, dari: https://katadata.co.id/agustiyanti/berita/5e9a4214bc 69e/jokowi-bentuk-gugus-tugas-percepatanpenanganan-covid-19

Detik.com (2020) Timeline Setengah Tahun COVID-19 di Indonesia. Diakses pada 12 September dari, https://news.detik.com/berita/d- 5156199/timeline-setengah-tahun-covid-19-diindonesia/1.

Humas. (15 Maret 2020). Minta Masyarakat Tenang, Presiden: Saatnya bekerja, belajar dan Beribadah dari rumah. Diakses pada 25 September 2020, dari https://setkab.go.id/minta-masyarakattenang-presiden-saatnya-bekerja-belajar-danberibadah-dari-rumah/

Jayani, Dwi Hadya. 26 Maret 2020. 10 Media yang paling sering digunakan di Indonesia. Diakses dari:

https://databoks.katadata.co.id/datapublish/2020/02/ 26/10-media-sosial-yang-paling-sering-digunakandiindonesia\#: : :text=Youtube $\% 20$ menjadi\%20platfor m\%20yang\%20paling, \%25\%2C\%20dan\%20Instagr am\%2079\%25

Munir. (2012). Multimedia, Konsep dan Aplikasi dalam Pendidikan. Alfabeta, Bandung.

Nasrullah, Rulli. (2014). Teori dan Riset Media Siber (Cibermedia). Kencana. Prenadamedia Grup. Jakarta.

Suyanto,M. (2005). Multimedia, Alat Untuk Meningkatkan Keunggulan Bersaing. Penerbit Andi: Yogyakarta. 